\title{
Cognitive Perspectives of Dog Owners about Correct Rearing Practices in Punjab, India
}

\author{
Yerramareddy Roopa", Rajesh Kasrija, H.K. Verma and S.K. Kansal
}

Department of Veterinary and Animal Husbandry Extension Education, Guru Angad Dev Veterinary and Animal Sciences University (GADVASU), Ludhiana, Punjab, India

*Corresponding author

\section{A B S T R A C T}

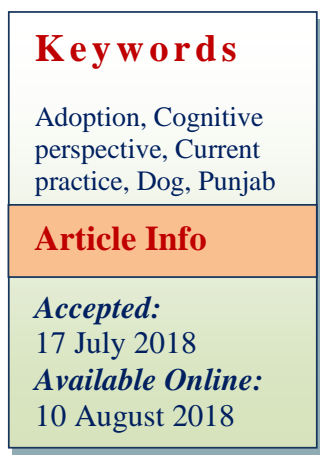

The present study was conducted in Teaching Veterinary clinical complex (TVCC) Guru Angad Dev Veterinary and Animal Sciences University and in different districts of Punjab on randomly selected 200 dog owners i.e., 100 from urban (Group I) and 100 from rural (Group II) with the help of pretested interview schedule. Various current practices followed by dog owners about dog feeding, housing, breeding and health and management were mentioned in the study. Group I dog owners were following more correct practices than their counter parts. So, the location and cognitive perspective of dog owners should be considered while organizing any extension programme. The feeding, housing, breeding and health and management practices were adopted by 50\%, 56\%, 27\% and $49 \%$ in Group I; and $28 \%, 24 \%, 15 \%$ and $29 \%$ dog owners in Group II respectively. Unawareness was the main factor for non-adoption of correct practices, indicating the dire need of organization of more extension campaigns for creating awareness among masses about correct rearing practices.

\section{Introduction}

Dog is treated as human best and loyal friend and was domesticated earlier than 15000 years ago. The companionship of dog is increasing day by day among all categories of people. There is no demarcation between urban-rural, rich-poor and young-old for dog rearing. From the past, dogs are reared for many purposes such as hunting, defending and livestock guarding (Coppinger and Schneider, 1995). These days, the concern of dog owners regarding correct rearing practices is increasing as dog owners considers dog as their family member. Research institutes are toiling day and night for developing latest technologies. Also, the extension machinery are disseminating latest knowledge to dog owners by organizing different programmes. However, for planning and successful implementation of any extension programme, the cognitive perspective of dog owners about current rearing practices can play an important role as it apprises an extension agent about strength and weakness of a rearing system. Also, the awareness about factors affecting adoption of correct practices can help in determining the hurdles for successful implementation of an extension programme. So, the present study was planned to study 
about current rearing practices followed by dog owners and factors affecting adoption of correct practice.

\section{Materials and Methods}

The present study was conducted in Teaching Veterinary clinical complex (TVCC) Guru Angad Dev Veterinary and Animal Sciences University, Ludhiana and in different districts of Punjab. A total of 200 dog owners, belonging to urban background (Group I, $\mathrm{n}=100$ ) and rural background (Group II, $\mathrm{n}=100$ ) were randomly selected. Thedog owners were personally interviewed with the help of pretested interview schedule about current rearing practices such as feeding, housing, breeding, health and management. If dog owners are following correct practice then they were given score 'One' and for wrong practice 'Zero' score. The collected date was tabulated and analysed with the help of SAS 9.3 system Carry N C, USA.

\section{Results and Discussion}

\section{Current dog rearing practices}

\section{Feeding practices}

Table 1 shows that $60 \%$ of the Group I and $71 \%$ of the Group II dog owners were changing the feed abruptly. Sudden change in food causes gastric problems in dogs. $47 \%$ of the group I and $79 \%$ of Group II dog owners were not making food separately for dog at home. However, most of Indian kitchen use onions and garlic for preparation of homemade food. Harvey et al., (1985) conducted the experiment by oral administration of onion to dogs to evaluate the hematological changes in a sequence. He reported that most of the anaemic dogs had evidence of intravascular hemolysis, reticulocytosis and slight increase in methemoglobin content. Yamato et al., (2005) reported almost same symptoms in male miniature schnauzer after ingesting garliccontaining food. So, presence of onion and garlic in homemade food can causes hemolytic anaemia in dogs.

Most (80\%) of Group II dog owners were feeding homemade food to their dogs. Only $10 \%$ of the Group I and 5\% of the Group II dog owners were feeding commercial food alone for their dogs. Both commercial and homemade foods are feeding to their dogs by $40 \%$ of the Group I and $15 \%$ of Group II dog owners. Rohlf et al., (2012) reported that the percent of dog owners feeding their dogs one time and two times daily are $41.5 \%$ and $56.1 \%$ respectively. The type of food they are providing are $38.0 \%$ commercially prepared dry food, $22.7 \%$ combination of commercial food and home-prepared food, $18.1 \%$ feeding mostly bones and meat and remaining 14.6\% fed home-prepared food to their dog. Gadegaonkar et al., (2014) reported that use of homemade food for growing puppy's leads to obesity in the puppies. The use of commercial pet food achieved the ideal absolute growth performance of growing puppies. So, feeding of commercial pet food lead to more uniform and healthy body development with the beneficial effect on blood parameters than homemade food.

$50 \%$ of Group I and $30 \%$ of Group II were feeding two times per day. 50\% of the Group II dog owners were feeding three times per day and $40 \%$ of Group I dog owners were feeding 3 times per day. Seneviratne et al., (2016) reported that $51 \%$ of them fed dogs two times per day, $41 \%$ fed three times per day, $7 \%$ fed one meal per day and $1 \%$ were four meals per day.

$25 \%$ of the Group II dog owners were keeping food on the floor for dogs. Murphy et al., (2012) reported that the incidence of canine obesity appears to be increasing dramatically 
and understanding factors impacting the amount of food pet owners provide to their dogs may improve weight management. It emphasizes the need for owner to use standard measuring cups for feeding $60 \%$ of the Group I dog owners and $20 \%$ of the Group II dog owners are using additional feed supplements in dog food. Only $10 \%$ of the Group I and $10 \%$ of Group II dog owners are providing fresh and clean water thrice a day.

\section{Housing practices}

A perusal of Table 2 indicates that regarding shelter for dog, 38\% of the Group I dog owners were providing kennel, 60\% keeping the dog in their own house and $2 \%$ are keeping dogs in animal shed. 30\% of Group II dog owners were not providing shelters to dog, 25\% providing kennels, 30\% keeping their dogs in their own house and $15 \%$ in animal shed.

Areas of sleeping for dog in urban areas were kennel (35\%), owner house (17\%), owner bed (25\%) and anywhere $20 \%$. In rural areas $25 \%$ of dogs sleep in the kennel, $30 \%$ in owner house, $2 \%$ on owner bed, and $45 \%$ anywhere. Ramirez and Hernandez (2014) collected data from 602 individuals from Mexico, after analysis it showed that during night times, most of the dogs $(67.4 \%)$ sleep in the yard or garbage and others i.e., $15.4 \%$ sleep inside the house, $9 \%$ sleep in the owner bedroom, $6.9 \%$ sleep on bed with owner, and $1.3 \%$ sleep in other areas.

\section{Breeding practices}

Table 3 shows that $70 \%$ of the Group I dog owners and $50 \%$ of the Group II dog owners were crossing their dog two times. $30 \%$ of the Group I dog owners and $5 \%$ of Group II dog owners were going for neutering their dog. $60 \%$ of the Group I dog owners and $55 \%$ of the Group II dog owners were crossing their dogs at the age of 2 years. Only $30 \%$ of Group I and $20 \%$ of Group II dog owners are weaning pups at correct age. Jokinen et al., (2017) reported that dogs homed at 6 -7 weeks, 8 weeks, 9-12 weeks, and 13-16 weeks are $31 \%, 41 \%, 23 \%$, and $5 \%$ respectively. Dogs, which are homed, more than 8 weeks old showed more aggressive behaviour than others did.

\section{Health and management practices}

Table 4 depicts that $85 \%$ of group II dog owners are not maintaining health records. Only $10 \%$ of Group II dog owners were following regular vaccination, remaining $40 \%$ doing irregularly and $50 \%$ were not vaccinating their dogs.

Jayakumar et al., (1998) reported that among previously vaccinated dogs, the percentage of dogs vaccinated regularly and irregularly were $25.12 \%$ and $74.88 \%$. Only $35 \%$ of the Group I and $10 \%$ of Group II dog owners were following regular deworming.

Combing increases the blood supply to skin and makes the dog's hair coat more lustrous. But only $25 \%$ of Group II dog owners were combing their dogs.

From this most of Group II dog owners i.e., $70 \%$ were using human comb rather than dog comb. From $25 \%$, only $10 \%$ of Group II the dog owner are combing twice per day.

There is no fixed place for grooming of dog said by $40 \%$ of the Group I and $50 \%$ of the Group II dog owners. Rohlf et al., (2012) reported that most of the dog owners i.e. 78.8 $\%$ go for regular grooming, but frequency of grooming differs and $10.3 \%$ go for grooming at least once a day. Most of the dog owners agreed that grooming was important (76.6\%), necessary $(75.3 \%)$ and good for the dog's health $(83.4 \%)$, important necessary. 
Table.1 Current dog feeding practices adopted by dog owners

\begin{tabular}{|c|c|c|c|c|}
\hline Practice & Category & $\begin{array}{l}\text { Group I } \\
(\mathrm{n}=100)\end{array}$ & $\begin{array}{c}\text { Group II } \\
(\mathbf{n}=100)\end{array}$ & $\begin{array}{c}\text { Over all } \\
(\mathbf{n}=90)\end{array}$ \\
\hline \multirow[t]{2}{*}{ Change in diet } & Abrupt & $60(60)$ & $71(71)$ & $131(65.5)$ \\
\hline & Gradual & $40(40)$ & $29(29)$ & $69(34.5)$ \\
\hline \multirow{2}{*}{$\begin{array}{l}\text { Making food } \\
\text { separately for } \\
\text { dog at home }\end{array}$} & No & $47(47)$ & $79(79)$ & $126(63)$ \\
\hline & Yes & $53(53)$ & $21(21)$ & $63(31.5)$ \\
\hline \multirow[t]{3}{*}{ Food } & Home made & $50(50)$ & $80(80)$ & $130(65)$ \\
\hline & Commercial & $10(10)$ & $5(5)$ & $15(7.5)$ \\
\hline & Both & $40(40)$ & $15(15)$ & $55(27.5)$ \\
\hline \multirow{4}{*}{$\begin{array}{l}\text { Time allowed } \\
\text { for eating food }\end{array}$} & Less than 5 minutes & $10(10)$ & $5(5)$ & $15(7.5)$ \\
\hline & 5- <10minutes & $15(15)$ & $16(16)$ & $31(15.5)$ \\
\hline & 10 -15 minutes & $35(35)$ & $10(10)$ & $45(22.5)$ \\
\hline & More than 15 minutes & $50(50)$ & $69(69)$ & $119(59.5)$ \\
\hline \multirow{2}{*}{$\begin{array}{l}\text { Removal of } \\
\text { feeding bowl }\end{array}$} & In free time & $80(80)$ & $95(95)$ & $175(87.5)$ \\
\hline & $\begin{array}{l}\text { Immediately after } \\
\text { feeding }\end{array}$ & $20(20)$ & $5(5)$ & $25(12.5)$ \\
\hline \multirow{4}{*}{$\begin{array}{l}\text { Frequency of } \\
\text { meal per day }\end{array}$} & Two times & $50(50)$ & $30(30)$ & $80(40)$ \\
\hline & Three times & $40(40)$ & $50(50)$ & $90(45)$ \\
\hline & Four times & $8(8)$ & $10(10)$ & $18(9)$ \\
\hline & Adlib & 2(2) & $10(10)$ & $12(6)$ \\
\hline \multirow{2}{*}{$\begin{array}{l}\text { Where food is } \\
\text { placed }\end{array}$} & Floor & $0(0)$ & $25(25)$ & $25(12.5)$ \\
\hline & Bowl & $100(100)$ & $75(75)$ & $175(87.5)$ \\
\hline \multirow{2}{*}{$\begin{array}{l}\text { Addition of } \\
\text { supplements in } \\
\text { food }\end{array}$} & No & $40(40)$ & $20(20)$ & $60(30)$ \\
\hline & Yes & $60(60)$ & $20(80)$ & $140(70)$ \\
\hline \multirow{3}{*}{$\begin{array}{l}\text { Providing fresh } \\
\text { and clean water }\end{array}$} & One time & $30(30)$ & $70(70)$ & $100(50)$ \\
\hline & Two times & $60(60)$ & $20(20)$ & $80(40)$ \\
\hline & Three times & $10(10)$ & $10(10)$ & $20(10)$ \\
\hline
\end{tabular}

Figure in parenthesis indicate percentage 
Table.2 Current dog housing practices adopted by dog owners

\begin{tabular}{|c|c|c|c|c|}
\hline Practice & Category & $\begin{array}{l}\text { Group I } \\
(n=100)\end{array}$ & $\begin{array}{l}\text { Group II } \\
(\mathbf{n}=\mathbf{1 0 0})\end{array}$ & $\begin{array}{l}\text { Over all } \\
(n=200)\end{array}$ \\
\hline \multirow{4}{*}{$\begin{array}{l}\text { Shelter place for } \\
\text { dog }\end{array}$} & No & $0(0)$ & $30(30)$ & $30(15)$ \\
\hline & Kennel & $38(38)$ & $25(25)$ & $63(31.5)$ \\
\hline & Owner house & $60(60)$ & $30(30)$ & $90(45)$ \\
\hline & Animal shed & $2(2)$ & $15(15)$ & $17(8.5)$ \\
\hline \multirow[t]{4}{*}{ Area for sleeping } & Kennel & $38(38)$ & $25(25)$ & $63(31.5)$ \\
\hline & Owner house & $17(17)$ & $30(30)$ & $47(23.5)$ \\
\hline & Owner bed & $25(25)$ & $2(2)$ & $27(13.5)$ \\
\hline & Anywhere & $20(20)$ & $45(45)$ & $65(32.5)$ \\
\hline \multirow[t]{4}{*}{ Roof of house } & Grill & $10(10)$ & $20(20)$ & $30(15)$ \\
\hline & Plastic sheet & $25(25)$ & $20(20)$ & $45(22.5)$ \\
\hline & Cement (Human dwelling) & $65(65)$ & $30(30)$ & $105(52.5)$ \\
\hline & Nothing & $0(0)$ & $30(20)$ & $20(10)$ \\
\hline \multirow[t]{4}{*}{ Floor of house } & Marble (Human dwelling) & $60(60)$ & $25(25)$ & $85(42.5)$ \\
\hline & Wood & $20(20)$ & $20(20)$ & $40(20)$ \\
\hline & Straw & $2(2)$ & $20(20)$ & $22(11)$ \\
\hline & Nothing & $0(0)$ & $10(10)$ & $10(5)$ \\
\hline \multirow{2}{*}{$\begin{array}{l}\text { Bedding material } \\
\text { in summer } \\
\text { season }\end{array}$} & Cotton cloth & $45(45)$ & $20(20)$ & $65(32.5)$ \\
\hline & Nothing & $55(55)$ & $80(80)$ & $143(71.5)$ \\
\hline \multirow{3}{*}{$\begin{array}{l}\text { Bedding material } \\
\text { in winter season }\end{array}$} & Bed & $60(60)$ & $10(10)$ & $70(35)$ \\
\hline & Thick woolen cloth & $38(38)$ & $70(70)$ & $108(54)$ \\
\hline & Straw & $2(2)$ & $20(20)$ & $22(11)$ \\
\hline \multirow{2}{*}{$\begin{array}{l}\text { Changing of } \\
\text { bedding material }\end{array}$} & No & $40(40)$ & $80(80)$ & $120(60)$ \\
\hline & Yes & $60(60)$ & $20(20)$ & $80(40)$ \\
\hline
\end{tabular}

Figure in parenthesis indicate percentage

Table.3 Current dog breeding practices adopted by dog owners

\begin{tabular}{|l|l|c|c|c|}
\hline Practice & Category & $\begin{array}{c}\text { Group I } \\
(\mathbf{n = 1 0 0})\end{array}$ & $\begin{array}{c}\text { Group II } \\
(\mathbf{n = 1 0 0})\end{array}$ & $\begin{array}{c}\text { Over all } \\
(\mathbf{n = 2 0 0})\end{array}$ \\
\hline $\begin{array}{l}\text { Frequency of } \\
\text { mating bitch }\end{array}$ & Once & $5(5)$ & $2(2)$ & $7(3.5)$ \\
\hline Two times & $70(70)$ & $50(50)$ & $120(60)$ \\
\hline Neutering of dog & No & $25(25)$ & $48(48)$ & $73(36.5)$ \\
\cline { 2 - 5 } & Yes & $70(70)$ & $95(95)$ & $165(82.5)$ \\
\hline Age at first & 1 year & $30(30)$ & $5(5)$ & $35(17.5)$ \\
\hline breeding & 2 years & $40(40)$ & $45(45)$ & $85(42.5)$ \\
\hline Age of weaning & One week & $25(25)$ & $40(40)$ & $65(32.5)$ \\
\hline pups & Two weeks & $25(25)$ & $25(25)$ & $50(25)$ \\
\hline & One month & $20(20)$ & $15(15)$ & $35(17.5)$ \\
\hline
\end{tabular}

Figure in parenthesis indicate percentage 
Table.4 Current dog health and management practices adopted by dog owners

\begin{tabular}{|c|c|c|c|c|}
\hline Practice & Category & $\begin{array}{l}\text { Group I } \\
(\mathbf{n}=100)\end{array}$ & $\begin{array}{l}\text { Group II } \\
(\mathbf{n}=100)\end{array}$ & $\begin{array}{l}\text { Over all } \\
(n=200)\end{array}$ \\
\hline \multirow[t]{4}{*}{ Record keeping } & No & $60(60)$ & $85(85)$ & $145(72.5)$ \\
\hline & Card & $25(25)$ & $10(10)$ & $35(17.5)$ \\
\hline & Book/Diary & $5(5)$ & $5(5)$ & $10(5)$ \\
\hline & Mobile & $10(10)$ & $0(0)$ & $10(5)$ \\
\hline \multirow[t]{3}{*}{ Vaccination } & No & $10(10)$ & $50(50)$ & $60(30)$ \\
\hline & Regular & $50(50)$ & $10(10)$ & $60(30)$ \\
\hline & Irregular & $40(40)$ & $40(40)$ & $80(40)$ \\
\hline \multirow[t]{3}{*}{ Deworming } & No & $20(20)$ & $60(60)$ & $80(40)$ \\
\hline & Regular & $35(35)$ & $10(10)$ & $45(22.5)$ \\
\hline & Irregular & $45(45)$ & $30(30)$ & $75(37.5)$ \\
\hline \multirow[t]{4}{*}{ Handling of dogs } & Chain & $20(20)$ & $30(30)$ & $50(25)$ \\
\hline & Leash & $40(40)$ & $10(10)$ & $50(25)$ \\
\hline & Rope & $10(10)$ & $25(25)$ & $35(17.5)$ \\
\hline & Free & $30(30)$ & $35(35)$ & $65(32.4)$ \\
\hline \multirow[t]{2}{*}{ Combing } & No & $55(55)$ & $75(75)$ & $139(65)$ \\
\hline & Yes & $45(45)$ & $25(25)$ & $70(35)$ \\
\hline \multirow[t]{2}{*}{ Bathing } & No & $51(51)$ & $70(70)$ & $121(60.5)$ \\
\hline & Yes & $49(49)$ & $30(30)$ & $79(39.5)$ \\
\hline \multirow[t]{2}{*}{ Nail Trimming } & No & $65(65)$ & $85(85)$ & $150(75)$ \\
\hline & Yes & $35(35)$ & $15(15)$ & $50(25)$ \\
\hline \multirow[t]{3}{*}{ Face cleaning } & Daily & $2(2)$ & $5(5)$ & $7(3.5$ \\
\hline & Weekly & $40(40)$ & $25(25)$ & $65(32.5)$ \\
\hline & Monthly & $58(58)$ & $70(70)$ & $128(64)$ \\
\hline \multirow[t]{3}{*}{ Area of grooming } & Inside home & $20(20)$ & $30(30)$ & $50(25)$ \\
\hline & Outside home & $40(40)$ & $20(20)$ & $60(30)$ \\
\hline & No fixed place & $40(40)$ & $50(50)$ & $90(45)$ \\
\hline \multirow[t]{2}{*}{ Use of Dog deodorants } & No & $55(55)$ & $95(95)$ & $150(75)$ \\
\hline & Yes & $45(45)$ & $5(5)$ & $50(25)$ \\
\hline \multirow[t]{2}{*}{ Training given to dog } & No & $75(75)$ & $95(95)$ & $170(85)$ \\
\hline & Yes & $25(25)$ & $5(5)$ & $30(15)$ \\
\hline \multirow[t]{2}{*}{ Training taken by dog owners } & No & $100(100)$ & $100(100)$ & $200(100)$ \\
\hline & Yes & $0(0)$ & $0(0)$ & $0(0)$ \\
\hline \multirow[t]{2}{*}{ Going out with dog for a walk } & No & $30(30)$ & $50(50)$ & $80(40)$ \\
\hline & Yes & $70(70)$ & $50(50)$ & $120(60)$ \\
\hline \multirow[t]{4}{*}{ Frequency of exercise per day } & Once per day & $40(40)$ & $20(20)$ & $60(30)$ \\
\hline & Twice per day & $45(45)$ & $38(38)$ & $83(41.5)$ \\
\hline & Thrice per day & $5(5)$ & $0(0)$ & $5(2.5)$ \\
\hline & No exercise & $10(10)$ & $42(42)$ & $52(26)$ \\
\hline \multirow[t]{3}{*}{ Time for exercise } & 10 minutes & $15(15)$ & $5(5)$ & $20(10)$ \\
\hline & 20 minutes & $60(60)$ & $35(35)$ & $95(47.5)$ \\
\hline & 30minutes & $25(25)$ & $60(60)$ & $85(42.5)$ \\
\hline Practice & Category & $\begin{array}{l}\text { Group I } \\
(\mathrm{n}=100)\end{array}$ & $\begin{array}{l}\text { Group II } \\
(n=100)\end{array}$ & $\begin{array}{l}\text { Over all } \\
(n=200)\end{array}$ \\
\hline \multirow{2}{*}{ Place for exercise } & Indoor & $40(40)$ & $15(15)$ & $55(27.5)$ \\
\hline & Outdoor & $70(70)$ & $80(80)$ & $150(75)$ \\
\hline \multirow[t]{2}{*}{ Change of exercise area } & No & $40(40)$ & $60(60)$ & $100(50)$ \\
\hline & Yes & $60(60)$ & $40(40)$ & $100(50)$ \\
\hline \multirow[t]{3}{*}{ Time spent with the dog } & Less than one hour per day & $20(20)$ & $40(40)$ & $60(30)$ \\
\hline & One to two hours per day & $30(30)$ & $40(40)$ & $70(35)$ \\
\hline & More than two hours per day & $50(50)$ & $20(20)$ & $70(35)$ \\
\hline
\end{tabular}

Figure in parenthesis indicate percentage. 
Table.5 Adoption status among dog owners of rural and urban areas

\begin{tabular}{|c|c|c|c|c|c|c|}
\hline \multirow[t]{2}{*}{ Group } & \multirow{2}{*}{\multicolumn{2}{|c|}{ Adoption status }} & \multicolumn{4}{|c|}{ Correct dog rearing practice } \\
\hline & & & $\begin{array}{l}\text { Feeding } \\
\text { practice }\end{array}$ & $\begin{array}{l}\text { Housing } \\
\text { Practice }\end{array}$ & $\begin{array}{l}\text { Breeding } \\
\text { practice }\end{array}$ & $\begin{array}{c}\text { Health and } \\
\text { management } \\
\text { practice }\end{array}$ \\
\hline \multirow{5}{*}{$\underset{(n=100)}{\text { G-I }}$} & Adopted & & $50(50)$ & $56(56)$ & $27(27)$ & $49(49)$ \\
\hline & \multirow[t]{4}{*}{ Non adopted } & Unawareness & $28(28)$ & $16(16)$ & $25(25)$ & $25(25)$ \\
\hline & & Cost factor & $14(14)$ & $16(16)$ & $8(8)$ & $13(13)$ \\
\hline & & $\begin{array}{c}\text { Lack of resource and technical } \\
\text { service }\end{array}$ & $4(4)$ & $4(4)$ & $5(5)$ & $3(3)$ \\
\hline & & Complexity of technology & $4(4)$ & $6(6)$ & $35(35)$ & $10(10)$ \\
\hline \multirow{5}{*}{$\underset{(n=100)}{G-I I}$} & Adopted & & $28(28)$ & $24(24)$ & $15(15)$ & $29(29)$ \\
\hline & \multirow[t]{4}{*}{ Non adopted } & Unawareness & $28(28)$ & $26(26)$ & $30(30)$ & $30(30)$ \\
\hline & & Cost factor & $22(22)$ & $24(24)$ & $15(15)$ & $20(20)$ \\
\hline & & $\begin{array}{c}\text { Lack of resource and technical } \\
\text { service }\end{array}$ & $12(12)$ & $10(10)$ & $20(20)$ & $11(11)$ \\
\hline & & Complexity of technology & $10(10)$ & $16(16)$ & $20(20)$ & $10(10)$ \\
\hline \multirow{5}{*}{$\begin{array}{l}\text { Overall } \\
(n=200)\end{array}$} & Adopted & & $40(20)$ & $40(20)$ & $21(10.5)$ & $39(19.5)$ \\
\hline & \multirow[t]{4}{*}{ Non adopted } & Unawareness & $28(14)$ & $21(10.5)$ & $28(14)$ & $28(14)$ \\
\hline & & Cost factor & $18(9)$ & $20(10)$ & $12(6)$ & $16(8)$ \\
\hline & & $\begin{array}{c}\text { Lack of resource and technical } \\
\text { service }\end{array}$ & $8(4)$ & $7(3.5)$ & $13(6.5)$ & $7(3.5)$ \\
\hline & & Complexity of technology & $6(3)$ & $12(6)$ & $26(13)$ & $10(5)$ \\
\hline
\end{tabular}

Figure in parenthesis indicate percentage 
Only 25\% of Group I and 5\% of Group II dog owners given training to their dog. Rohlf et al., (2010) conducted online survey and reported that $96 \%$ agreed that training promotes the relationship between their dog and owner, $90.6 \%$ said that it keeps dogs safe, $89.9 \%$ agreed that it reduces dogs nuisance. $88.2 \%$ said friends and family agree to this practice, $86.6 \%$ said it prevents harming other people and animals by and $58 \%$ perceived that it is important.

$42 \%$ of the Group II dog owners were not giving any exercise to dog. Rohlf et al., (2012) reported that $60.2 \%$ of dog owners said their dog received exercise at least one time daily, $20 \%$ reported five to six times exercise per week, $15.7 \%$ reported three to four times per week, and remaining $2.8 \%$ reported only once or twice per week. Some owners reported that their dog received adequate exercise but they did not. Most of the owners agreed that exercise is good for dog's health, behaviour, increase bond between dog and owner, for weight and body management.

Time spent with dog is more in case of Group I dog owners than Group II dog owners. Kobelt et al., (2003) conducted their survey on 203 dog owners and reported that dogs develop excessive barking, aggression, digging, escaping, and destructiveness when they are socially isolated.

\section{Factors affecting adoption of correct practice}

Table 5 clearly represents the adoption and non-adoption level of different practices by Group I and Group II dog owners. The feeding, housing, breeding and health and management practices were adopted by $50 \%$, $56 \%, 27 \%$ and $49 \%$ dog owners in Group I; and $28 \%, 24 \%, 15 \%$ and $29 \%$ dog owners in Group II respectively. Unawareness is the main factor for non-adoption of these practices. So, more extension campaigns should be organized for creating awareness among masses about correct rearing practices. Rohlf et al., (2010) also reported that using educational campaigns and appropriate role models in advertisement campaigns to promote responsible dog management behaviours, including training, may provide a means to engage people in these behaviours. Cost factor also played a significant role in non-adoption of correct practice, indicating that adoption of low cost technologies is more. Similarly, Yadav and Yadav (1995) also found that level of adoption was more in zero cost practices as compared to high cost. Adoption of correct practices are more in Group I when compared to Group II.

The present study focuses on cognitive perspective of dog owners about rearing practices. Urban dog owners are following more correct practices as compared to rural dog owners. So, while planning any extension programme location of trainee and their cognitive perspective should be taken in to consideration. Unawareness is the main factor for non-adoption of correct practices. So suitable extension strategies should be followed for enhancing knowledge level of dog owners.

\section{References}

Coppinger, R. and Schneider, R. (1995). Evolution of working dogs. In: Serpell J (Ed.). The Domestic Dog: Its Evolution, Behavior, and Interaction with People. Cambridge University Press, Cambridge, UK, pp. 21-50.

Gadegaonkar, G. M., Kale, S. A., Patil, M. B. and Kank, V. D. (2014).Comparative growth performance of puppies on homemade and commercial Nonvegetarian food. Indian Journal of Canine Practice 6(1): 85-86. 
Harvey, J. W. and Rackear, D. (1985). Experimental onion-induced haemolytic anemia in dogs. Vet.Pathol. 22: 387-92.

Jayakumar, R., Kumanan, K., Chandramohan, A., Tirumuragan, G., Gowri, M. M., Velmurugan, R., Nachimuthu, K. and Padmanaban, V. D. (1998). Organization of mass vaccination campaigns for rabies control in India. Biomedicine 18(1): 19-24.

Jokinen, O., Appleby, D., Saxén, S. S., Appleby, T. and Valros, A. (2017). Homing age influences the prevalence of aggressive and avoidance-related behaviour in adult dogs. Appl Anim Behav Sci 195: 87-92.

Kobelt, A. J., Hemsworth, P. H, Barnett, J. L. and Coleman, G. J. (2003). A survey of dog ownership in suburban Australia: conditions and behaviour problems. ApplAnimBehav Sci 82: 137-48.

Murphy, M., Lusby, A. L., Bartges, J. W. and Krik, C. A. (2012). Size of food bowl and scoop affects amount of food owners feed their dogs. J Anim. Physiol. Anim. Nutr. 98(2): 237-41.

Ramirez, M. T. G. and Hernandez, R. L. (2014). Benefits of dog ownership: Comparative study of equivalent samples. J. Vet.Behav.9: 311-15.
Rohlf, V. I., Bennett, P. C., Toukhsati, S. and Coleman, G. (2010). Why do even committed dog owners fail to comply with some responsible ownership practices? Anthrozoos 23(2): 143-55.

Rohlf, V. I., Bennett, P. C., Toukhsati, S. and Coleman, G. (2012). Beliefs underlying dog owner's health care behaviors: Results from a Large, Self- Selected, Internet Sample, Anthrozoos 25(2): 17185

Seneviratne, M., Subasinghe, D. W. D. and Watson, P. J. (2016). A survey of pet feeding practices of dog owners visiting a veterinary practice in Colombo, Sri Lanka. Veterinary Medicine and Science 2: 106-16.

Yadav, B. L. and Yadav, M. C. (1995). Adoption level and index of Buffalo husbandry practices in the home tract of Murrah. Indian J Anim. Prod. Mgmt. 11: 4-13.

Yamato, O., Kasai, E., Katsura, T., Takahashi, S., Shiota, T., Tajima, M., Yamasaki, M. and Maede, Y. (2005). Heinz body haemolytic anemia with eccentrocytosis from ingestion of Chinese chive (Allium tuberosum) and garlic (Allium sativum) in a dog. J. Am. Anim. Hosp. Assoc. 41: 68-73.

\section{How to cite this article:}

Yerramareddy Roopa, Rajesh Kasrija, H.K. Verma and Kansal, S.K. 2018. Cognitive Perspectives of Dog Owners about Correct Rearing Practices in Punjab, India. Int.J.Curr.Microbiol.App.Sci. 7(08): 3023-3031. doi: https://doi.org/10.20546/ijcmas.2018.708.321 